Original Research Paper

\title{
Pelatihan English for Tourism (EFT) Bagi Pelaku Wisata Adat di Kabupaten Lombok Timur
}

\author{
Lalu Ali Wardana ${ }^{1 *}$, Santi Farmasari ${ }^{1}$, Baharudin1, Sribagus ${ }^{1}$ \\ ${ }^{\text {I}}$ Fakultas Keguruan dan IlmuPendidikan, Universitas Mataram, Mataram Indonesia;
}

https://doi.org/10.29303/jpmpi.v3i2.1110

Sitasi: Wardana, L. A., Baharudin., Sribagus \& Farmasari. (2021). Pelatihan English for Tourism (EFT) Bagi Pelaku Wisata Adat di Kabupaten Lombok Timur. Jurnal Pengabdian Magister Pendidikan IPA 4(4)

Article history

Received: 02 Oktober 2021

Revised: 20 Oktober 2021

Accepted: 07 November 2021

*Corresponding Author: Lalu Ali Wardana, Fakultas Keguruan dan IlmuPendidikan, Universitas Mataram, Mataram Indonesia;

Email:

aliwardana@unram.ac.id

\begin{abstract}
Indonesia adalah negara yang diakui dunia sebagai negara kepulauan sebagaimana yang dimuat dalam (UNCLOSE, 1982) yang dikutip oleh (Lasabuda, 2013). Ini menjadi potensi yang sangat besar untuk pengembangan pariwisata (Hijrriati dan Rina, 2014). Lombok sangat terkenal dengan keindahan alamnya baik wisata pantai dan pemandian seperti Gunung Rinjani (Permadi, 2018). Selain desa wisata yang terkenal dengan keindahannya, di Lombok juga terdapat beberapa desa adat yang layak dijadikan destinasi wisata yang menarik terutama bagi wisatawan yang menyukai kehidupan tridisonal masyarakat lokal. Dalam upaya pengembangan daerah dearah tersebut menjadi destinasi wisata baru, salah satu yang perlu dipersiapkan adalah kualitas SDM pelaku wisata terutama yang berkaitan dengan English For Tourism. English for Tourism(EFT) dibutuhkan sebagai media untuk melakukan komunikasi, negosiasi, dan transaksi baik dengan wisatawan lokal maupun mancanegara. Oleh karena itu, Kegiatan pengabdian ini akan sangat bermanfaat untuk meningkatkan kemampuan pelaku wisata dalam menggunakan bahasa inggris yang berkaitan dengan pariwisata atau English for Tourism. Selain itu, kegiatan ini juga dapat dijadikan ajang memperkenalkan program studi pendidikan bahasa inggris FKIP Unram sebagai salah satu program studi pencetak guru bahasa inggris dengan harapan minat pelaku wisata terutama yang masih bersetatus siswa masuk perguruan tinggi khususnya pendidikan bahasa inggris akan meningkat.
\end{abstract}

Keywords: Pelatihan; English For Tourism; Wisata Adat.

akan menarik wisatawan untuk berkunjung ke Indonesia dan akan memberikan keuntungan bagi negara maupun daerah tersebut (Hijrriati dan Rina, 2014). Dari berbagai wilayah yang ada di Indonesia Lombok merupakan pulau dengan keindahan alam yang sangat luar biasa.

Provinsi Nusa Tenggara Barat merupakan daerah yang memiliki potensi budaya dan alam yang sangat menunjang perkembangan wilayah berbasis pada pariwisata. Desa wisata yang sangat populer sebagai objek wisata di NTB yaitu Desa Wisata Sukarara dan Desa Wisata Rembitan. Kedua desa ini terletak di Kabupaten Lombok Tengah. Sementara itu, Lombok Timur juga memiliki Desa Wisata yang tidak kalah indahnya yaitu Desa 
Wisata Sembalun Bumbung, Desa Wisata Sembalun Lawang yang keduanya terletak di sebelah timur Rinjani, Gili Lampu, Pantai Sorga dan masih banyak lagi (Permadi et al., 2018).

Provinsi Nusa Tenggara Barat merupakan daerah yang memiliki potensi budaya dan alam yang sangat menunjang perkembangan wilayah berbasis pada pariwisata. Desa wisata yang sangat populer sebagai objek wisata di NTB yaitu Desa Wisata Sukarara dan Desa Wisata Rembitan. Kedua desa ini terletak di Kabupaten Lombok Tengah. Sementara itu, Lombok Timur juga memiliki Desa Wisata yang tidak kalah indahnya yaitu Desa Wisata Sembalun Bumbung, Desa Wisata Sembalun Lawang yang keduanya terletak di sebelah timur Rinjani, Gili Lampu, Pantai Sorga dan masih banyak lagi (Permadi et al., 2018).

Di samping itu, ada juga beberapa desa yang layak untuk dikembangkan menjadi destinasi wisata karena memiliki keunikan berupa adat istiadat lokal yang masih dipegang erat oleh penduduknya. Desa Padamara, Lendang Nangka, Selaparang, misalnya, adalah desa yang dikenal sebagai desa yang memegang kuat tradisi lama sehingga sering dijadikan rujukan oleh banyak pihak untuk menyelenggarakan acara adat. Desa tersebu ini juga memiliki keindahan alam yang cukup memikat yang berupa hamparan sawah yang luas serta memiliki landscape yang tidak kalah menarik dengan desa wisata lainnya dan memiliki potensi sebagai objek wisata yang menarik apabila dibenahi secara serius.

Yang dirasa kurang adalah promosi serta kesiapan warga lokal atau pelaku pariwisata apabila menerima kunjungan wisatawan terutama yang berasal dari luar negeri. Oleh karena penguasaan bahasa inggris sebagai bahasa internasional sebagai media promosi serta media komunikasi dengan wisatawan manca negara menjadi kebutuhan yang mendesak. Bahasa inggris yang dibutuhkan adalah bahasa inggris for tourisme yang memang khusus dipersiapkan bagi mereka yang bekerja dibidang pariwisata.

\section{Metode}

Metode yang digunkan dalam kegiatan pengabdian ini adalah pelatihan pada pelaku wisata di beberapa desa adat di Lombok Timur dengan melalui beberapa tahapan yaitu: tahap persiapan, tahap pelaksanaan, dan tahap evaluasi. a. Persiapan

Persiapan rencana program pengabdian masyarakat di Lombok Timur ini dengan mengidentifikasi beberapa desa adat yang memiliki potensi untuk dijadikan desa adat. Beberpa pemuda yang berasal dari desa tersebut kemudian dihubungi melalui pemerintah desa untuk dilatih bahasa inggris.

\section{b. Tahap Pelaksanaan}

Pada tahap pelaksanakan; pada tahap ini pelaku wisata dilatih tentang englih for tourism sesuai dengan jadwal yang telah disepakati oleh tim pengabdian dan para pelaku wisata.

\section{c. Tahap Evaluasi}

Pada tahap evaluasi ini, tim melakukan evaluasi terhadap proses pembelajaran yang dilakukan. Hal ini bertujuan untuk perbaikan proses serta untuk persiapan rencana tindak lanjut.

\section{Hasil dan Pembahasan}

\section{Pengenalan potensi wisata}

Penataan taman jati menjadi potensi eduwisata merupakan salah satu program utama dari team pengabdian. Secara umum taman adalah sebuah tempat yang terencana atau sengaja direncanakan yang dibuat untuk menampilkan keindahan dari berbagai tanaman dan bentuk alami. Adapun taman jati Padamara menampilkan keindahan alami dari pohon-pohon jati, sehingga masyarakat Desa Padamara dapat menikmati taman jati dengan suasana khas Desa Padamara yang memiki rasa kenyamanan tersendiri.

\section{a. Persiapan}

Penataan taman jati sebagai potensi eduwisata mendapat antusias yang positif dari warga desa. Tim pengabdian Bersama dengan kelompok masyarakat Desa Padamara melakukan diskusi pengembangan taman jati agar menjadi sebuah taman yang dapat bernilai eduwisata bagi para pengunjung. Adapun proses pngembangan yang dilaksanakan berupa; pembersihan taman jati, Pembuatan meja dan tempat duduk, pembuatan spot foto, pembuatan papan kratif, penanaman tanaman hias dari sayuran sawi, pembuatan pintu masuk dan pagar bintang, pengecatan meja, pembuatan berugak, pemasangan ayunan dari ban bekas dan ayuanan ikat (hammoxks) dan Perawatan kebun jati secara berkelanjutan. 


\section{b. Pelaksanaan}

Pelaksanaan ditargetkan selama dua minggu dan akan dilakukan pengoreksian atapun kelengkapan atribut yang diperlukan sesuai kebutuhan pada waktu yang tidak terjadwalkan. Setelah didapatkan hasil dari diskusi yang dilakukan, kemudian direalisasikan hasil diskusi yang telah disepakati.

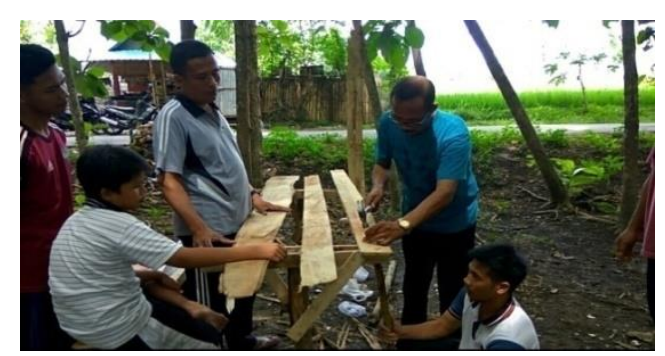

Gambar 1. Proses pembuatan meja dan tempat duduk

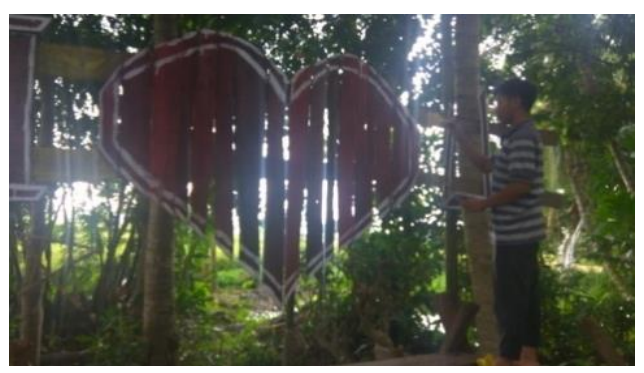

Gambar 2. Pembuatan Spot Foto

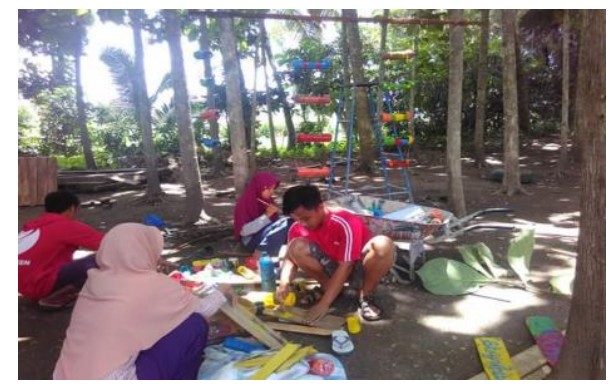

Gambar 3. Pembuatan Papan kreatif dan Proses penanaman tanaman hias

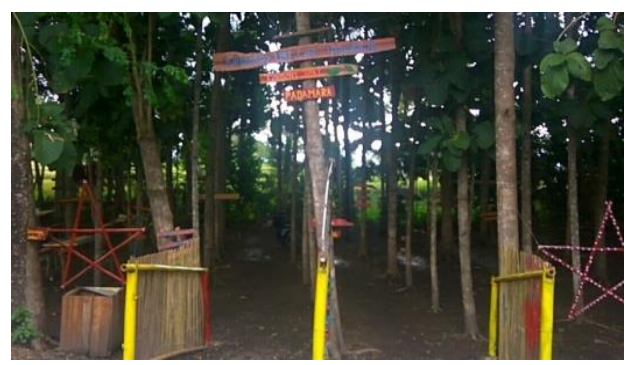

Gambar 4. Pembuatan pintu masuk ke taman jati

Perawatan dilakukan setiap hari yaitu waktu pagi dan sore perawatan berupa pembersihan sekitar taman jati dengan cara menyapu daun-daun yang jatuh kemudian dibakar di tempat yang sudah disediakan, selanjutnya penyiraman tanaman dilakukan setiap hari untuk mencegah tanaman yang sudah ditanam baik sawi atau tanaman hias tidak mati, perawatan dilakukan oleh teammpengabdian Bersama dengan masyarakat dengan cara membagi tugas, sebagian team bertugas menyapu dan sebagian lagi bertugas menyiram tanaman.

\section{Pelatihan Englih for Tourism}

Pelatihan bahasa inggris dilakukan oleh tim pengabdian yang melibatkan beberapa mahasiswa. Pada tahap awal, peserta diberikan pemahaman tentang potensi wisata di Lombok sebagai dampak dari penyelenggaraan beberapa event internasional di pulau ini. Potensi tersebut harus dimanfaatkan semaksimal mungkin supaya dapat meningkatkan taraf hidup mereka.

Dengan demikian, diharapkan bahwa motivasi akan dapat meningkat.

Setelah itu, para peserta diberikan tentang pemahaman tentang English for tourism serta rencana pelatihannya. Pelatihan ini akan meningkatkan kemampuan berbicara, mendengar, membaca dan menulis. Mesikipun demikian, penekanan akan diberikan pada aspek bicara. Keterampilan ini dibutuhkan untuk berkomunikasi secara efektif dalam berbagai konteks professional.

Ada beberapa topik yang dibahas yang berkaitan dengan English for Tourism antara lain reserving room, asking price, asking things, asking for opinion, asking for help, making a request, tourist and guide, renting a car, a holiday booking, dst.

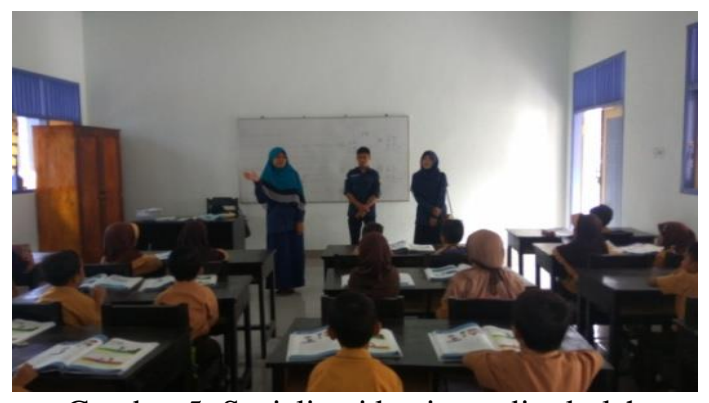

Gambar 5. Sosialisasi kegiatan di sekolah 


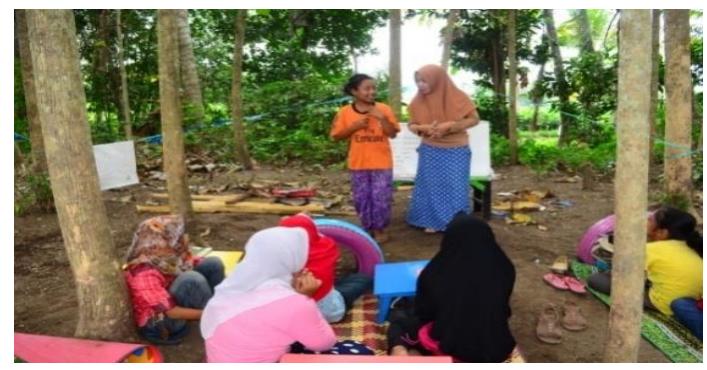

Gambar 6. Pelatihan english for tourisme

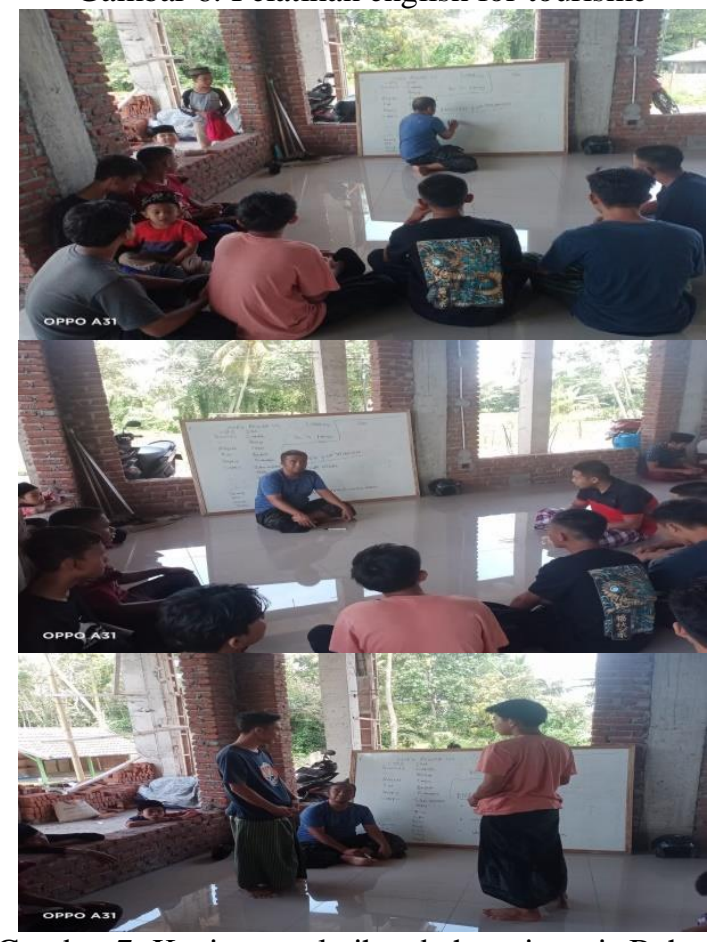

Gambar 7. Kegiatan pelatihan bahasa inggris Bahasa Inggris

Hasil dari keterlaksanaan program ini dapat dilihat dari jumlah peserta les setiap pertemuan. Semakin banyak atau stabil pesertanya maka pelaksanaan program kerja ini dapat dikatakan berhasil.

\section{Kesimpulan}

Pengabdian mengenai pengembangan potensi dduwisata melalui tata kelola sumber daya alam dan lingkungan di Desa Padamara Kecamatan Sukamulia Kabupaten Lombok Timur, NTB dilaksanakan selama 45 hari di Desa Padamara Kecamatan Sukamulia dengan program utama yaitu Pelatihan diberikan satu kali dalam 1 minggu yang melibatkan mahasiswa dan tim pengabdian. Hal ini dilakukan sebagai respon dari tingginya minat peserta untuk mengikuti pelatihan ini. Pelatihan yang awalnya direncanakan diselesaikan dalam 3 kali pertemuan, masih tetap dilaksanakan dan bahkan diusulkan oleh berbagai pihak untuk dapat dijadikan sebagai kegiatan berkelanjutan mengingat tingginya antusiasme peserta yang dipengaruhi oleh kesadaraan tentang manfaatnya

\section{Daftar Pustaka}

Adi. L. P., Thatok. A., Harmi. W dan Hilmiati.. 2018. Identifikasi Desa Wisata Di Kecamatan Jerowaru, Kabupaten Lombok Timur. Jurnal Parawisata Terapan. Vol. 2(1) 33-35.

Angga. H. D. 2017. Pengembangan Obyek Dan Dan Daya Tarik Wisata Alam Sebagai Daerah Tujuan Wisata Di Kabupaten Karanganyer. Jurnal Sosiologi DILEMA. Vol. 32(1) 34-44. ISSN: 0215/9635.

Ati. S. S. 2017. Pengembangan TBM Sebagai Sarana Meningkatkan Minat Baca Masyarakat. Jurnal ANUVA. Vol. 1(1) 19-32. ISSN: 2598/3040.

Cempaka. O. J., Yuniwati., Yuli. S. 2013. Peran Taman Baca Masyarakat Dalam Menumbuhkan Minat Baca Anak Di Taman Baca Masyarakat "MORTIR" Banyumanik-Semarang. Jurnal Ilmu Perpustakaan. Vol. 2(2). 1-10.

Ferdinan. Y., Mochamad. M., Heru. R. 1013. Pengembangan Wisata Alam Berbasis Ekowisata Dalam Perspektif Pelayanan Publik (Studi pada Disparjuk Kabupaten Ngajuk). Jurnal Admistrasi Publik (JAP). Vol. 3 (12) 2123-2127.

Hidat Marceilla. 2011. Strategi Perencanaan dan Pengembangan Objek Wisata (Studi Kasus Pantai Pangandaran Kabupaten Ciamis Jawa Barat). Jurnal Tourism and Hospitality Essentials. Vol. 1(1).

Hijriati Emma dan Ria. M. 2014. Pengaruh Ekowisata Berbasis Masyarakat Terhadap Perubahan Kondisi Ekologi, Sosial dan Ekonomi di Kampung Batu Suhunan, Sukabumi. Juenal Sosial Pedesaan. Vol. 2(3). ISSN. 2302-7517.

Lasabuda Ridwan. 2013. Pembangunan Wilayah Pesisir Dan Lautan Dalam Perspektif Negara Kelautan Republik Indonesia. Jurnal Ilmiah Platax. Vol. 12. ISSN: 2302-3589.

Lestari Gina. 2015. Bhinneka Tunggal Ika: Khasanah Multi Kultural Indonesia Di Tengah Kehidupan Sara. Jurnal Pendidikan Pancasila dan Kewarganegaraan. Program Studi Ketahanan Nasional Universitas Gajah Mada. Vol: 28 (1). 
Petrus. B. S. 2012. Pengembangan Taman Baca Masyarakat Sebagai Sumber Belajar. Jurnal Ilmu VISI P2TK PAUD NI. Vol. 7(1) 42-56. 